\title{
Intracardiac metastasis of lung adenocarcinoma diagnosed by convex-probe EBUS
}

\author{
Diana Rey, ${ }^{1}$ Gonzalo Labarca, ${ }^{2}$ Ivan Caviedes, ${ }^{3}$ Sebastian Fernandez-Bussy ${ }^{3}$
}

${ }^{1}$ Departamento Enfermedades Respiratorias, Hospital Universitario San Ignacio, Pontificia Universidad Javeriana, Bogota, Colombia ${ }^{2}$ Departamento Medicina Interna, Pontificia Universidad Catolica, Santiago, Chile ${ }^{3}$ Departamento Enfermedades Respiratorias, Clinica AlemanaUniversidad del Desarrollo, Santiago, Chile

Correspondence to Dr Gonzalo Labarca, glabarcat@gmail.com

Accepted 9 September 2014
CrossMark

To cite: Rey D, Labarca G, Caviedes I, et al. BMJ Case Rep Published online:

[please include Day Month Year] doi:10.1136/bcr-2014206769

\section{DESCRIPTION}

A 52-year-old woman, former smoker with no relevant medical history, presented with 2 months symptom of right hip pain that limited her walking. This was associated with dyspnoea Medical Research Council modified 2 and occasional dry cough. Physical examination revealed normal cardiopulmonary examination, and tenderness in the right proximal femur. Chest X-ray demonstrated a right lower lobe nodule. Chest CT scan showed scattered pulmonary nodules bilaterally, smaller than $20 \mathrm{~mm}$, enlarged mediastinal lymph nodes and a hypodense image along the right pulmonary vein, extended into the left atrium (LA; figure 1). Fluorodeoxyglucose positron emission tomography/CT showed significant uptake of pulmonary nodules, subcarinal lymph node, and the lesion extended to the LA, together with a right hip lesion.

Convex-probe endobronchial ultrasound (CP-EBUS) identified a vascularised $30 \mathrm{~mm}$ lesion, along the right pulmonary vein extending into the LA (figure 2). Needle aspiration was performed to the described mass and to the subcarinal lymph node. Both biopsies results were positive for lung adenocarcinoma, immunohistochemistry showed positive thyroid transcription factor-1(TTF-1), molecular analysis demonstrated a negative epidermal growth factor receptor (EGFR) and echinoderm microtubule-associated protein-like 4-anaplastic lymphoma kinase (EML4-ALK). The patient started chemotherapy, anticoagulation and localised radiotherapy in her right hip. Cardiac metastasis of lung cancer usually involves the pericardium or epicardium by direct invasion and/or lymphatic spread, however metastasis to the LA myocardium and endocardium are extremely rare. ${ }^{1}$

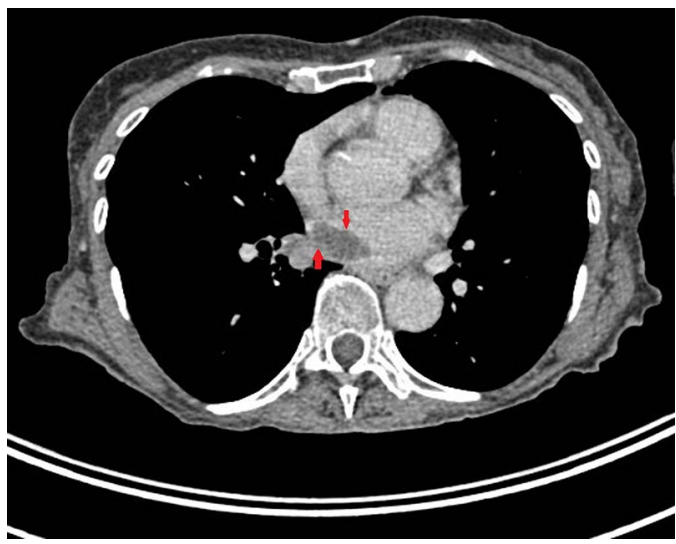

Figure 1 Chest CT scan showing a hypodense image along the right pulmonary vein extended into the left atrium (arrow).

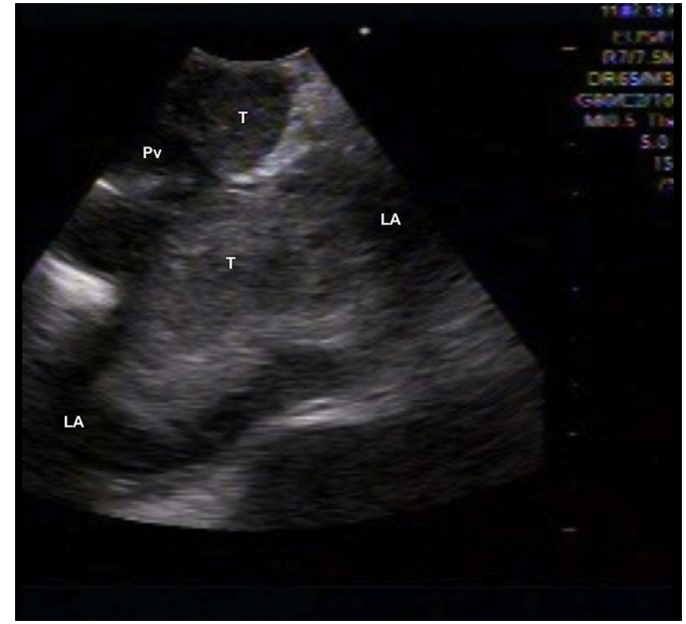

Figure 2 Convex-probe endobronchial ultrasound image demonstrating echogenic $30 \mathrm{~mm}$ tumour, along the right pulmonary vein extending into the $L A$ ( $L A$, left atrium; Pv, pulmonary vein; $\mathrm{T}$, tumour).

Lesions in the LA and proximal portions of great arteries can be visualised by CP-EBUS. ${ }^{2}{ }^{3}$

\section{Learning points}

- Cardiac metastasis of lung cancer is extremely rare.

- Convex-probe endobronchial ultrasound can be used to assess other mediastinal structures such as left atrium.

- Convex-probe endobronchial ultrasound is a safe and useful diagnostic tool.

Contributors All the authors contributed in the conception and design of the study, and acquisition of data. SF-B and DR were involved in the preparation of the manuscript and final proof read.

Competing interests None.

Patient consent Obtained.

Provenance and peer review Not commissioned; externally peer reviewed.

\section{REFERENCES}

1 Son JW, Hong GR. Unusual left ventricular endocardial metastasis from primary lung cancer. I Cardiovasc Ultrasound 2012;20:157-60

2 Cetinkaya E, Yılmaz A, Özgül A, et al. Left atrial mass demonstrated during endobronchial ultrasound session. Respiration 2011;81:57-8.

3 Folch E, Ibrahim O, Majid A. Cardiac wall mass identified by endobronchial ultrasonography. I Bronchology Interv Pulmonol 2013:20:364-6. 
Copyright 2014 BMJ Publishing Group. All rights reserved. For permission to reuse any of this content visit http://group.bmj.com/group/rights-licensing/permissions.

BMJ Case Report Fellows may re-use this article for personal use and teaching without any further permission.

Become a Fellow of BMJ Case Reports today and you can:

- Submit as many cases as you like

- Enjoy fast sympathetic peer review and rapid publication of accepted articles

- Access all the published articles

- Re-use any of the published material for personal use and teaching without further permission

For information on Institutional Fellowships contact consortiasales@bmjgroup.com

Visit casereports.bmj.com for more articles like this and to become a Fellow 